\title{
Feedback effects of clonal groups and tree clusters on site conditions at the treeline: implications for treeline dynamics
}

\author{
Friedrich-Karl Holtmeier ${ }^{1, *}$, Gabriele Broll $^{2}$ \\ ${ }^{1}$ Institute of Landscape Ecology, Heisenbergstraße 2, Westfälische Wilhelms-Universität, 48149 Münster, Germany \\ ${ }^{2}$ Institute of Geography, University of Osnabrück, Seminarstr. 19 a/b, 49074 Osnabrück, Germany
}

\begin{abstract}
The article examines interactions between closely spaced clonal tree groups (spruce, fir, mountain birch) and dense tree clusters and their environment with special regard to Northern Europe, the Alps, and the Rocky Mountains. Modification of wind velocity and direction, trapping blowing snow and eolian dust, ground-shading and the release of sensible heat to the immediate vicinity ('black-body effect') are the main direct feedback effects of grouped trees on site conditions. Under long-lived clonal groups, soil physical and chemical properties gradually change. Clonal groups also leave their marks in geomorphic micro-structures. Compact groups may facilitate establishment of tree seedlings by providing shelter. Under global warming, the existing clonal groups above the forest limit may act as 'new' sources of viable seed that facilitate infilling of gaps in the treeline ecotone and the establishment of new tree populations above the present tree limit. On the other hand, increased deposition of snow as a result of the presence of tree groups may affect seedling establishment, and thereby overrule the positive effects of climate warming. If climate warming continues, current spatial structures, surface roughness, albedo, and snow distribution pattern, along with the resulting effects of these factors, will change across the entire ecotone. The feedback effects of closely spaced clonal groups will spatially overlap. Thus, it will be hard to distinguish between the effects of the single groups when new trees become established within the existing gaps. The northward shift of the polar treeline ecotone might contribute to heating of the lower atmosphere. On steep high-mountain slopes, however, no similar effects can be expected because of the limited size of the lower alpine area that has the potential to become covered with new forest and tree stands.
\end{abstract}

KEY WORDS: Clonal groups - Spruce - Fir - Mountain birch · Black-body effect · Wind · Snowpack $\cdot$ Treeline pattern

\section{INTRODUCTION}

Feedback effects of trees, and tree groups in particular, on site conditions in the treeline ecotone have been little studied, even though these effects may exert a strong influence on soil temperatures, soil moisture, nutrients, soil forming processes and,

${ }^{*}$ Corresponding author: fkholtmeier@arcor.de

§Advance View was available online January 17, 2017 not least, microtopography. Since the end of the last century, however, this aspect has increasingly attracted attention (e.g. Marr 1967, Holtmeier 1980, Daly 1984, Callaway et al. 2002, Alftine \& Malanson 2004, Bekker 2005, Holtmeier 2005, 2009, Resler 2006, Zeng \& Malanson 2006, Humphries et al. 2008, Butler et al. 2009, Malanson et al. 2009, Holt-

() The authors 2017. Open Access under Creative Commons by Attribution Licence. Use, distribution and reproduction are unrestricted. Authors and original publication must be credited. 
meier \& Broll 2010, Weiss et al. 2015). The objective of the present study is to examine interactions between closely spaced tree groups and the treeline environment, with special regard to the role of tree groups' architecture and distribution patterns. Our own previous studies were carried out in treeline ecotones in northern Fennoscandia, the Alps (Europe), and the Rocky Mountains (North America). This study summarizes current knowledge. It is a timely contribution to the debate on treeline dynamics and their driving factors (e.g. Harsch et al. 2009).

Treeline ecotones are often characterized by tree groups of different ages and sizes, surrounded by alpine grass and/or dwarf shrub vegetation.

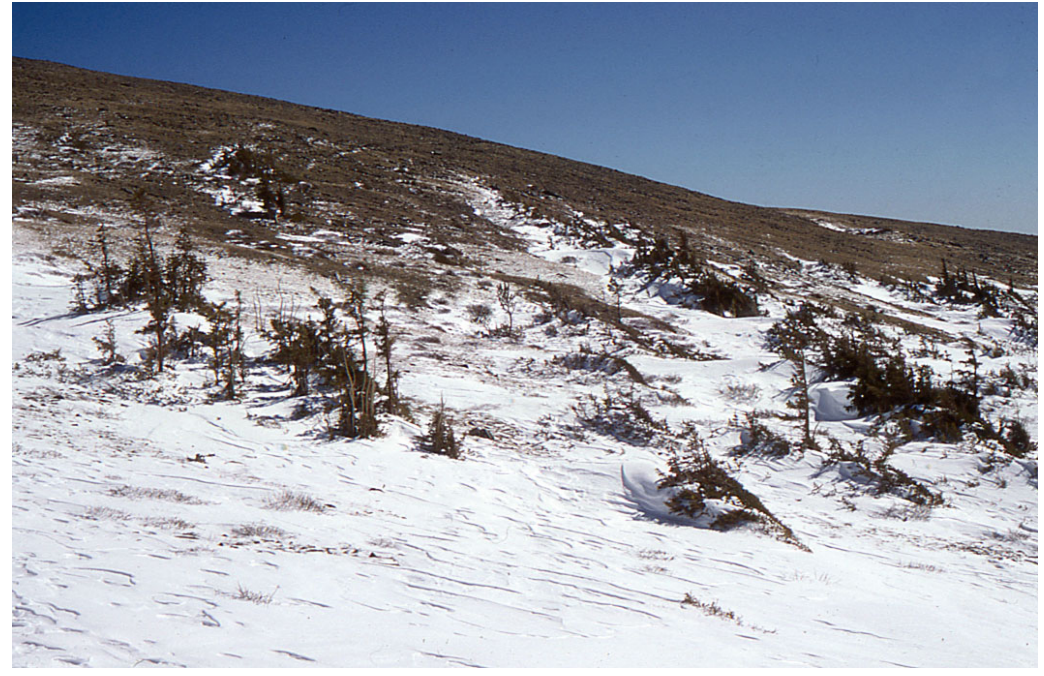

Fig. 1. Tree-line ecotone with clonal groups influencing snow pattern on a wind-exposed slope. Niwot Ridge, Colorado Front Range, USA, at about 3450 m. Photo by F.-K. Holtmeier, 2 March 1990

(plan view) with the mother trees in the center may occur. In extremely windy places, mats, as well as wedge-like and low hedge-like growth forms, prevail. The orientation of the hedges is parallel to the prevailing wind direction and to each other (cf. Fig. 1). Tree clusters typically occur for example in zoochoric pines (Pinus cembra, European Alps; $P$. flexilis, $P$. albicaulis, Rocky Mountains).

In the European Alps and in many other Eurasian mountain areas already settled in prehistoric times, the natural treeline zone where layering in spruce probably prevailed has now largely disappeared mainly due to pastoral use and fire (Holtmeier 1974). Wildfires also occur under present conditions. At the treeline, where trees grow very slowly, wildfires may cause serious damage, in particular to dense tree clusters and clonal groups (e.g. Holtmeier 2009, Holtmeier \& Broll 2010). Wildfires will probably be more frequent under warmer and drier conditions (e.g. Schumacher \& Bugmann 2006).

At the mountain treeline in northern Finland, south of the polar limit of spruce, and in the Swedish Scandes, clonal groups of Norway spruce are well represented (Fig. 2; e.g. Kullman 2007, 2012, Öberg \& Kullman 2011). In many areas of subarctic Northern Europe, compact groups of multistemmed mountain birch Betula pubescens ssp. tortuosa (Fig. 3) prevail, that sprouted from the rootstock after birch decline due to episodic defoliation by leaf-eating insects (Epirrita autumnata, Operophtera brumata; Bylund 1999, Neuvonen \& Wielgolaski 2005). 


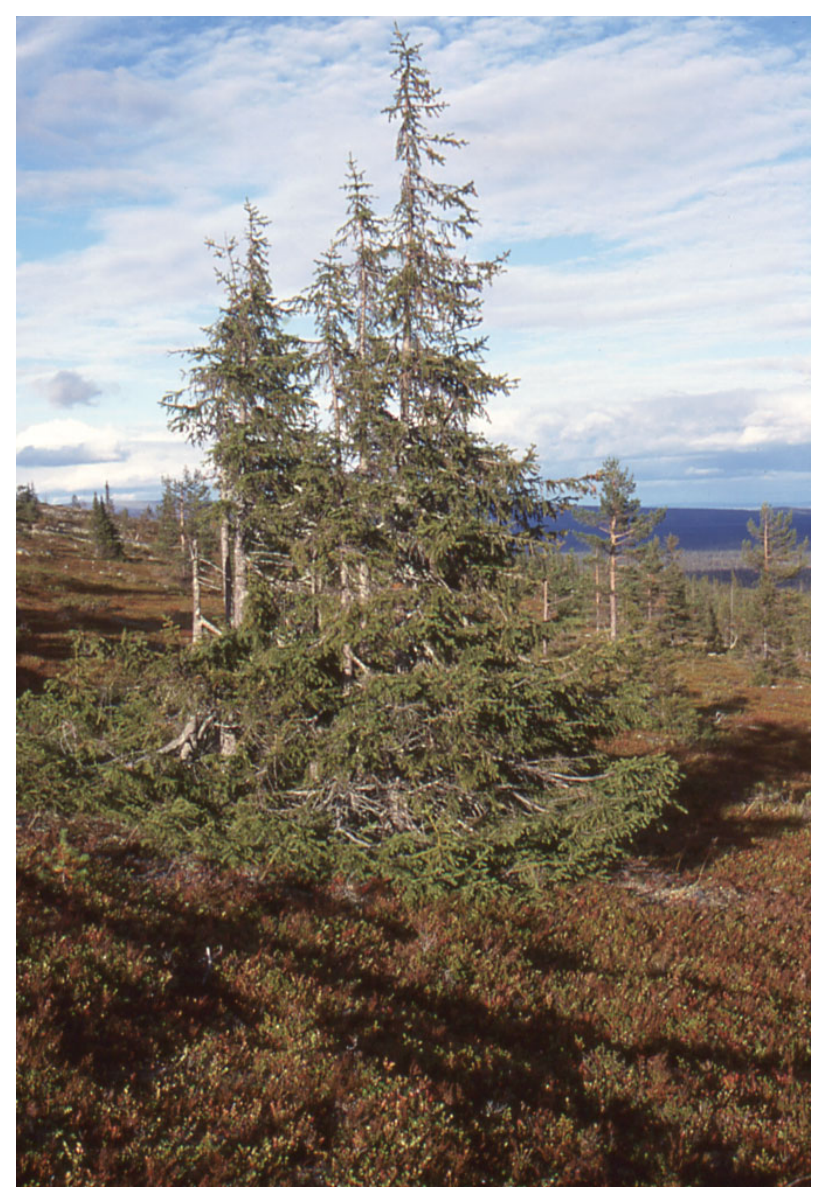

Fig. 2. Clonal Norway spruce Picea abies in the forest-alpine tundra ecotone on Yllästunturi, a fell in Finnish Lapland, at about $480 \mathrm{~m}$. Photo by F.-K. Holtmeier, 1 September 2000

\section{FEEDBACKS EFFECTS OF TREE GROUPS ON THEIR ENVIRONMENT}

Trees start to influence their close environment when projecting above the ground vegetation (e.g. dwarf shrubs) and the winter snowpack. The feedbacks from trees and tree groups depend largely on tree stature, stem density, architecture and species as well as on the interactions with local topography (Fig. 4; see also Holtmeier 2009, Holtmeier \& Broll 2010).

\subsection{Influence on direct solar radiation, and resultant effects}

Transformation of direct solar radiation into sensible heat and subsequent release to the environment by long-wave radiation and turbulent flux - all sub-

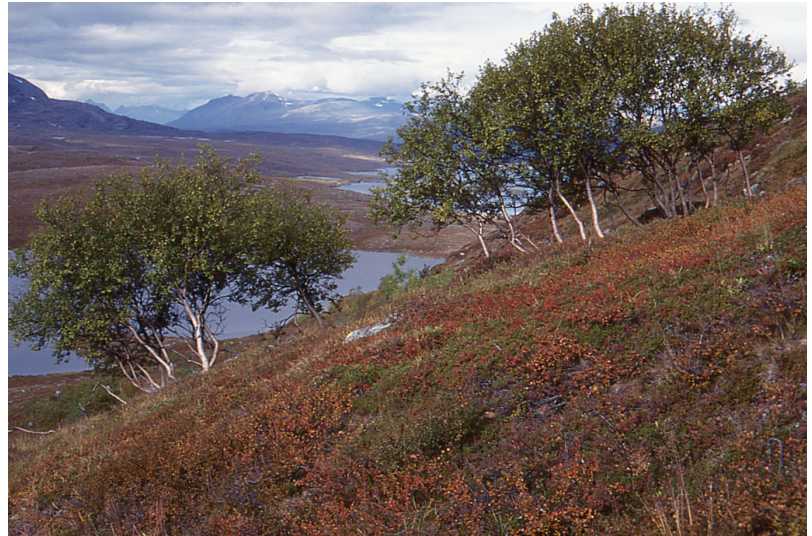

Fig. 3. Clonal groups formed by mountain birch Betula tortuosa and willow Salix caprea (with darker stems, at the right hand side) on Korkea Jeähkkraš, a mountain in the Kilpisjärvi area, NW Finland. Photo by F.-K. Holtmeier, 10 September 2000

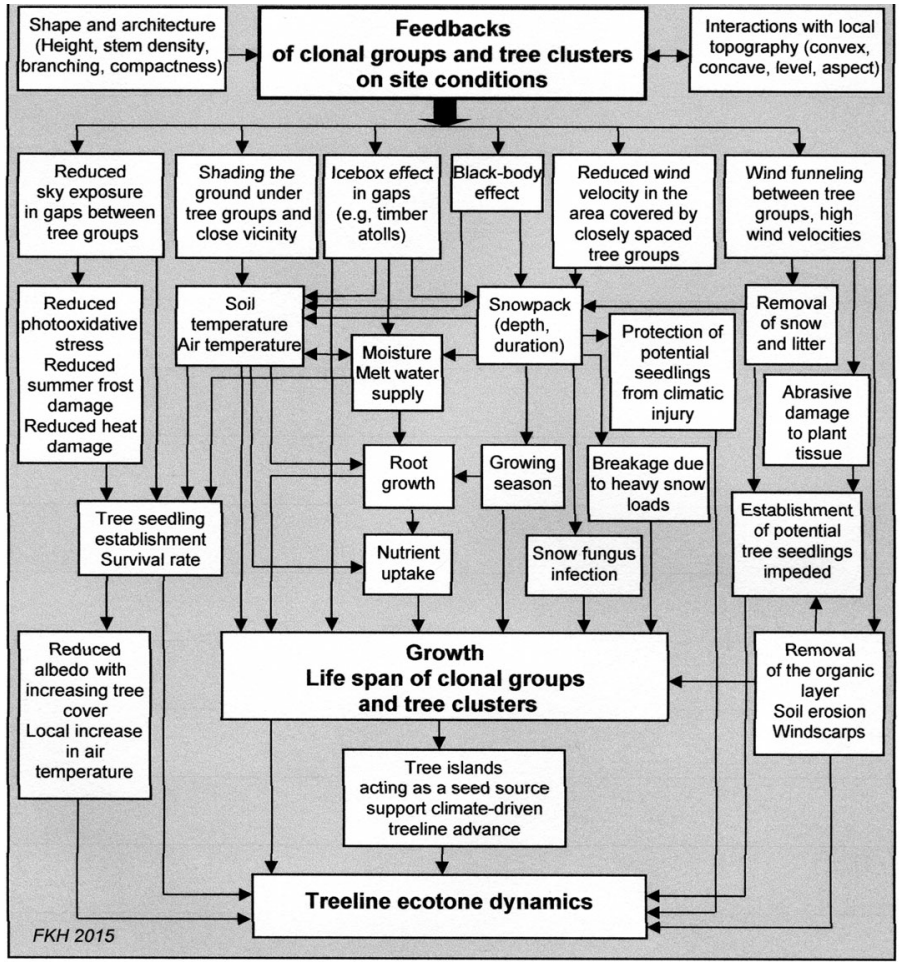

Fig. 4. Possible feedbacks of clonal tree islands and tree clusters on site conditions. Considerably modified from Holtmeier (2009)

ject to modification by wind velocity and direction-are important feedback effects of grouped trees (e.g. Holtmeier 1987, Oke 1987) (cf. Fig. 4). Due to the low albedo of conifers (0.05 to 0.15$)$ their sun-exposed sides rapidly warm up to $>10^{\circ} \mathrm{C}$ (maximum $\sim 20^{\circ} \mathrm{C}$ ) above the temperature of ambient air (e.g. Tranquillini 1957, 1979, Havranek \& Tanquillini 1995, Hadley \& Smith 1986). Thus, they act as a 
source of longwave radiation which is immediately absorbed by the surrounding snow and may cause early snowmelt at the directly south-facing sunexposed side of the trees. In addition, the ground (with lower albedo) may become exposed to solar radiation and warm up rapidly (Oke 1987). This effect of trees on snowmelt has been called the 'black-body effect' in treeline literature (e.g. Brink 1959, Habeck 1969, Franklin \& Dyrness 1973). The temperature of the exposed ground may rise and accelerate snowmelt. Nevertheless, wind and evaporation of melt water may delay the increase in soil temperature (e.g. Holtmeier 1987). The black-body effect can facilitate the establishment of tree seedlings (Fig. 5). Blowing snow accumulating at the sun-facing leeward side of tree groups may override the black body effect completely (Holtmeier 2009, Holtmeier \& Broll 2010).

Shading of the ground by compact tree groups plays an even bigger role in the treeline ecotone. Soil temperature under the canopy of tree groups is relatively low during the growing season and relatively high in winter, and moisture is high compared to open terrain (Holtmeier \& Broll 1992). In the open, temperatures rapidly rise in spring, with a positive influence on fine root development, nutrient uptake and seedling growth, provided that water supply is sufficient (Anschlag et al. 2008). In ecotones sparsely covered with low tree clusters and clonal groups, the total shaded area is relatively small. Thus, the uppermost soil layers and the air next to the ground surface may warm up during the day far above ambient temperature, unless prevented by wind and evaporation. In narrow gaps between high tree groups, however, most of the ground is usually in shade, and temperatures during the growing season are relatively low, compared to gaps of the same size surrounded, for example, by low krummholz (i.e. trees of which height growth is suppressed due to the adverse climatic conditions) or willow scrub. However, high trees surrounding narrow gaps minimize sky exposure and thus may mitigate photooxidative stress due to high daytime radiation loads combined with low night temperatures (e.g. Germino et al. 2002, Brodersen et al. 2006, Maher \& Germino 2006). In addition, outgoing long-wave radiation and nocturnal summer frosts are reduced (Germino \& Smith 1999, Smith et al. 2003, Johnson et al. 2004). Winter snowpack on the ground, however, often lingers into summer, even on southern aspects (see also Elliott \& Kipfmueller 2010, Elliott 2012, Elliott \& Cowell 2015). This 'icebox effect' also occurs in gaps resulting from death of the initial trees or older clone members in

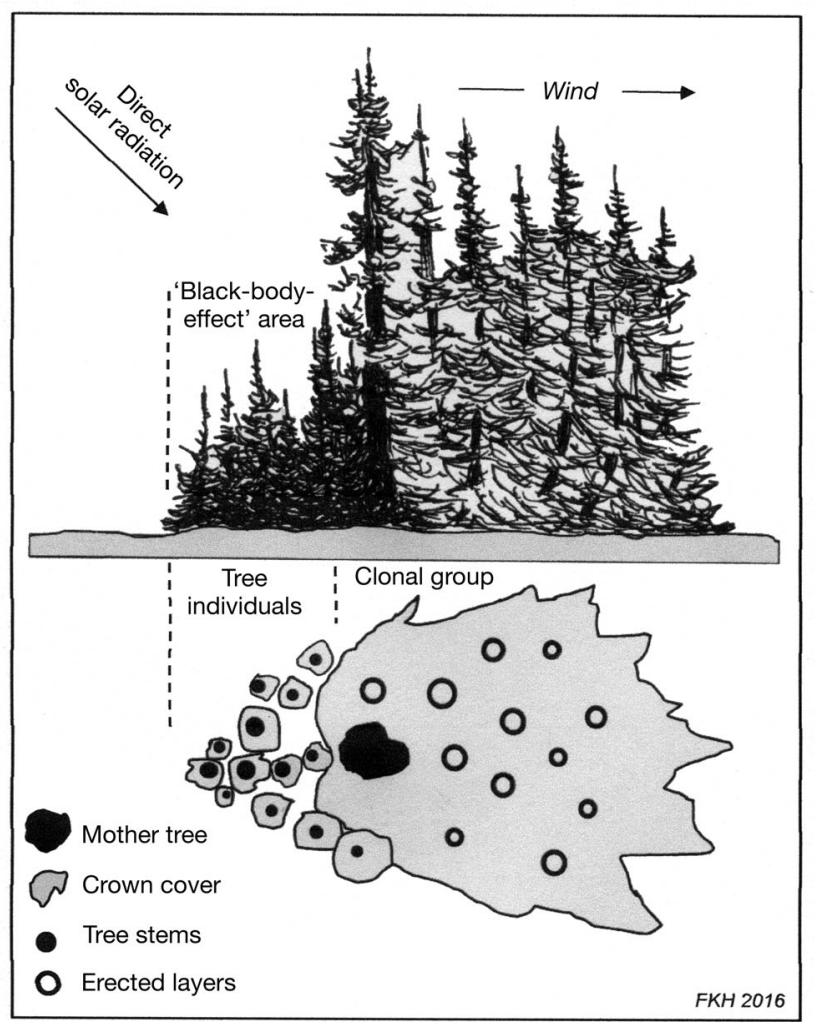

Fig. 5. Clonal group with younger trees that established themselves facilitated by the 'black-body effect'. Drawing by F.-K. Holtmeier after a field sketch. Erected layers are lateral branches that form adventitious roots, after which their distal end turns to a vertical position

more circular clonal groups ('timber atolls'; cf. Holtmeier 2005). Late-lying snow curtails the growing season. Tree seedlings are often destroyed by mechanical damage (settling snow) and/or infection by snow fungi (Herpotrichia juniperi, H. coulteri, Phacidium infestans) (Roll-Hansen 1989, NierhausWunderwald 1996, Senn 1999, Holtmeier 2005, 2009, Cunningham et al. 2006, Streule \& Häsler 2006, Butin 2011, Holtmeier \& Broll 2011, Barbeito et al. 2013).

\subsection{Influence of tree groups on wind and resultant effects}

Most treeline ecotones are in a windy environment (e.g. Holtmeier 1978, 2005, Hiemstra et al. 2002, 2006, Alftine \& Malanson 2004, Bekker 2005, Kullman 2007, 2012). Trees, tree clusters and compact clonal groups in particular, reduce wind velocity and modify wind flow pattern near the ground surface. Compact tree groups and open tree stands also trap more blowing snow compared to treeless mountain 
and northern tundra (cf. Fig. 1; Holtmeier 1996, Liston et al. 2002, Tape et al. 2006). Relatively open tree clusters usually collect snow inside, whereas a deep snowdrift piles up behind the compact clonal groups' leeward edge. Its length is often several times the height of the windward tree group. At the windward front of clonal groups and tree clusters, and also along their lateral edges, blowouts occur, where intense scouring effects (eddies) remove the winter snowpack. Closely spaced clonal groups may increase deposition of blowing snow to such an extent that even on wind-exposed slopes, where the winter snow cover would normally be very patchy or even absent, relatively large areas get buried under a deep and late-lying snowpack (cf. Fig. 1).

The effects of clonal groups and terrain on relocation of snow and its consequences often overlap (Holtmeier 2005). Snowdrifts at the downwind edge of clonal groups are usually shorter on slopes with prevailing upslope winds than those with downslope winds, as supply of blowing snow from the closed forest on windward slopes is limited. In contrast, on lee slopes, the alpine zone is usually a large source of blowing snow that is partly deposited as snowdrifts behind the downwind edge of clonal groups, in tree clusters and also within more open tree stands. The amount of accumulated drifting snow may be up to 20 times (e.g. Dyunin 1967, Kobayashi 1972), in extreme cases even 100 times (Blanken 2009) greater than that deposited by direct snowfall (see also Holtmeier 1987). Clonal groups and tree clusters on top of convex topography increase deposition of snow on the lee slope, which in any case is normally rich in snow (Holtmeier 1996, 2005).

Soil temperatures in leeward snowdrift areas and also inside clonal groups do not usually drop much below the freezing point due to the deep insulating snowpack (Aulitzky 1961, Brooks et al. 1995). However, deep and late-lying snowdrifts may keep soil temperatures low far into the growing season (Holtmeier \& Broll 1992, Hinkel \& Hurd 2006). Consequently, the onset of root growth is delayed (e.g. Turner \& Streule 1983). Root growth, nutrient uptake, photosynthesis, and carbon acquisition are reduced (e.g. Kramer 1982, Karlsson \& Nordell 1996). On the other hand, nonstructural carbon reserves (e.g. Sveinbjörnsson et al. 1992, Skre 1993, Grace et al. 2002, Hoch \& Körner 2003, Shi et al. 2006) may compensate for the effects of low soil temperature during the early growing season. In dry climates and during dry summers, moisture supply from melting snow drifts may mitigate moisture stress in late spring and early summer. As a result, comparatively luxuriant ground vegetation can be found in such places. Tree seedlings may also profit from extended moisture supply. On the other hand, at the treeline in Northern Europe and North America we found multi-stemmed clonal groups of spruce that locally increase deposition of blowing snow even on wind-swept convexities to an extent that needles and shoots of the lower branches encased in late-laying snow are destroyed by snow fungi. In the European Alps, Swiss stone pine Pinus cembra clusters that originated from seed caches of the European nutcracker Nucifraga caryocatactes on convex topography in the treeline ecotone may also act as a snow trap and increase the risk of snow fungus damage (Holtmeier 1974, 1985b, 2005). While the older trees lose all their lower needles, the younger pines and seedlings buried under the snowpack are completely destroyed (e.g. Holtmeier 1974, 2005, Stöcklin \& Körner 1999).

Clonal groups have a lasting influence not only on soil physical and chemical properties (Holtmeier \& Broll 1992) but also on geomorphic micro-structures, such as wind-scarps and small 10 to $20 \mathrm{~cm}$ high 'platforms' (Broll \& Holtmeier 1994). Dieback at their windward front and elongation by layering on their leeward side (ca. $2 \mathrm{~cm} \mathrm{yr}^{-1}$; Benedict 1984) can bring about a slow downwind migration of clonal groups (Fig. 6). Inside the clonal groups a deep litter layer

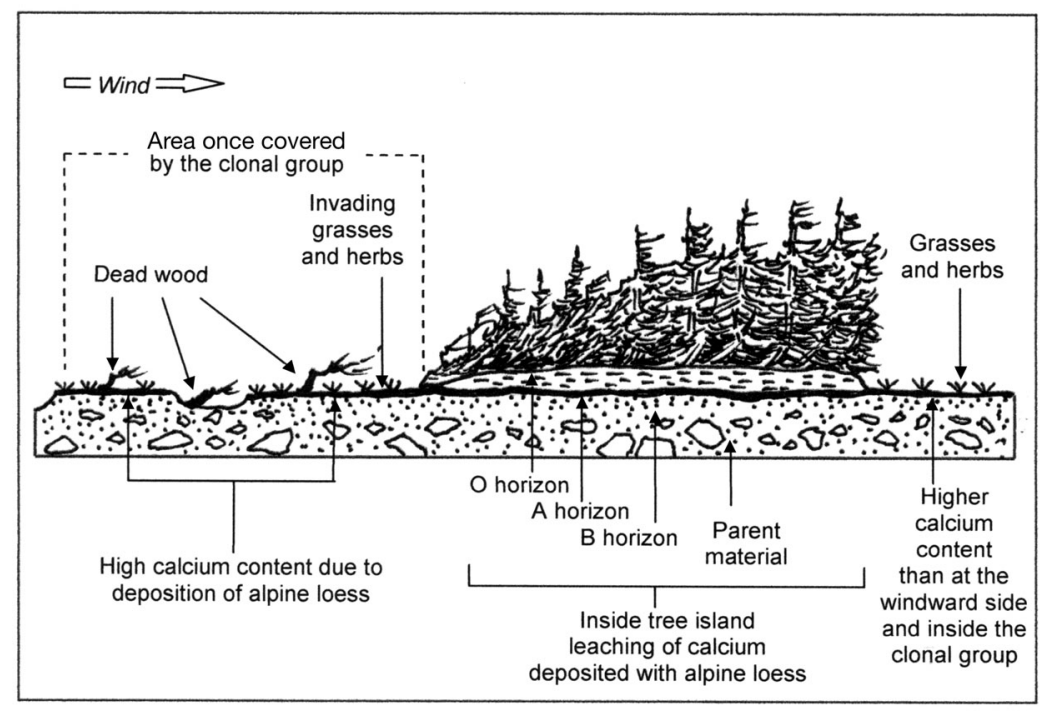

Fig. 6. Effects of a downwind 'migrating' clonal group. Modified from Broll \& Holtmeier (1994) 
accumulates. When the windward portions of the clonal groups are destroyed and the ground surface becomes exposed, the litter layer and the slightly decomposed organic matter $\left(\mathrm{O}_{\mathrm{f}}\right)$ horizon are the first to erode. At least a part of the highly decomposed organic matter $\left(\mathrm{O}_{\mathrm{h}}\right)$ horizon may be left intact, however. Almost simultaneously, alpine vegetation invades. This not only prevents further deflation and erosion for a while, but also increases deposition of calciumrich eolian dust ('alpine loess'; Thorn \& Darmody 1980, Litaor 1987, Holtmeier \& Broll 1992, Broll \& Holtmeier 1994). Eolian dust influences soil nutrient content, soil acidity, waterstoring capacity, heat conductivity and decomposition. Nitrogen-rich litter produced by invading herbs and

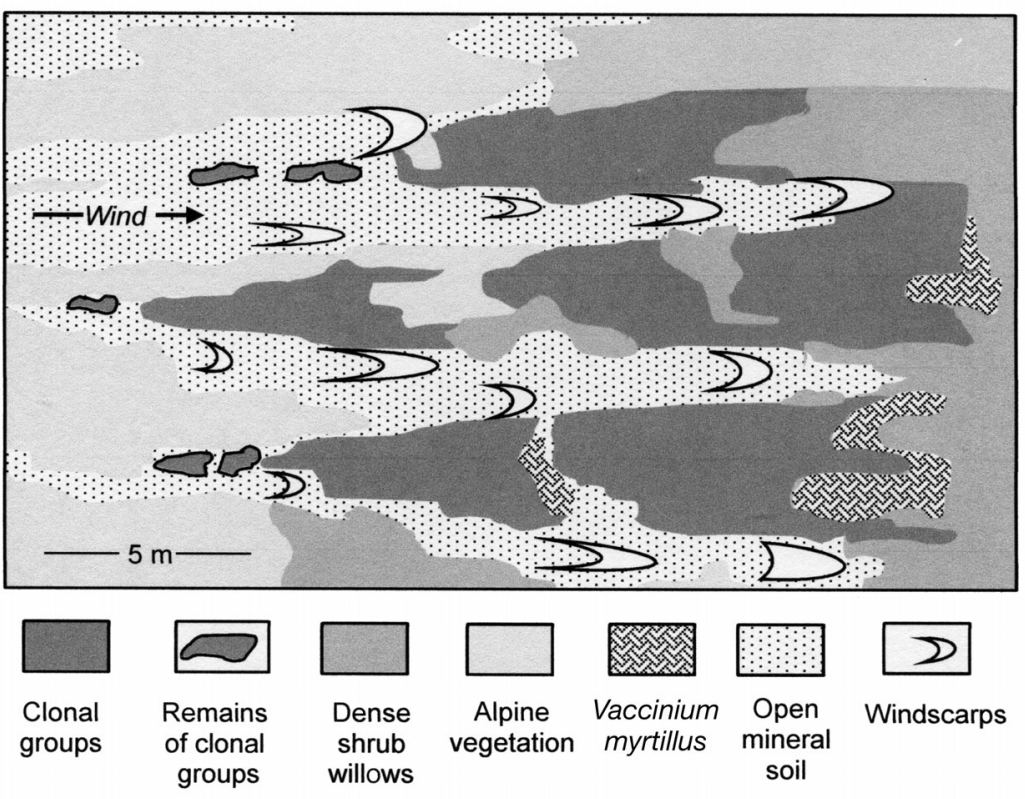

Fig. 7. Effects of wind funneling between compact clonal groups grasses, together with increased cation exchange capacity and relatively favorable soil moisture conditions, enhance humification in the topsoil. However, the wind-exposed edge of the tree island is partly eroded by wind. Needle ice formation often reinforces erosion. The resultant wind scarp gradually recedes in the downwind direction (Holtmeier \& Broll 1992, Broll \& Holtmeier 1994). Lateral erosion separates it into isolated small 10 to $20 \mathrm{~cm}$ high 'plateaus', with different physical and chemical soil conditions compared to the scarps still connected with the downwind migrating clonal groups (cf. Broll \& Holtmeier 1994). Additional evidence of treeisland migration is provided by dead wood remains in the soil and on the surface. The remaining humus profile slowly decomposes in the long term due to higher temperatures at the formerly shaded tree island site. However, as suggested by Benedict (1984) the E-horizon and well developed B-horizons can record tree island passage long after wood remains have rotted away. Comparable lasting effects of mountain birch groups on geomorphic micro-structures were also documented at treeline in northernmost Finland (Holtmeier et al. 2004).

Narrow 'corridors' between closely spaced 'hedges' or wedge-like clonal groups act as wind channels. In such places, strong winds often expose the mineral soil and create wind scarps (Fig. 7; Holtmeier 1978, 2005). Needle ice reinforces deflation and may impede or even prevent colonization by vegetation. At the leeward end of these corridors, however, where the wind funneling effect dwindles away,

herbs, grasses, willow shrubs Salix spp., and blueberry Vaccinium myrtillus become established. Low willow shrubs often also line the lateral sides of hedges if snowpack is deep enough in such places to provide shelter from climatic injuries. Such interactions are characteristic traits of the wind-swept tree island areas in the entire treeline ecotone on the Colorado Front Range and neighboring mountain ranges (e.g. Hiemstra et al. 2002). They are particularly conspicuous on gently sloping or level uplifted old land surfaces, whereas on steep and rugged terrain, effects of geomorphic structures and mass-wasting are often of major importance (Holtmeier 2009, Holtmeier \& Broll 2012). The same patterns have been documented by other treeline studies (e.g. Bekker 2005, Resler et al. 2005, Elliott 2012, Kharuk et al. 2010).

The influence of clonal groups and clusters of deciduous trees such as mountain birch or aspen on wind and snow relocation during winter is usually less conspicuous than that caused by evergreen conifer groups. However, in the treeline ecotone in Northern Europe, compact mountain-birch krummholz thickets, although without leaves in winter, collect drifting snow, even on wind-swept topography. Wind-trimmed wedge-like birches growing on top of convex topography or near the crest of the upper lee slope of convexities often produce a snowdrift at their downwind edge that enhances snow deposition on the lee slope rich in snow anyway. This is reflected in the occurrence and relatively luxuriant growth of 


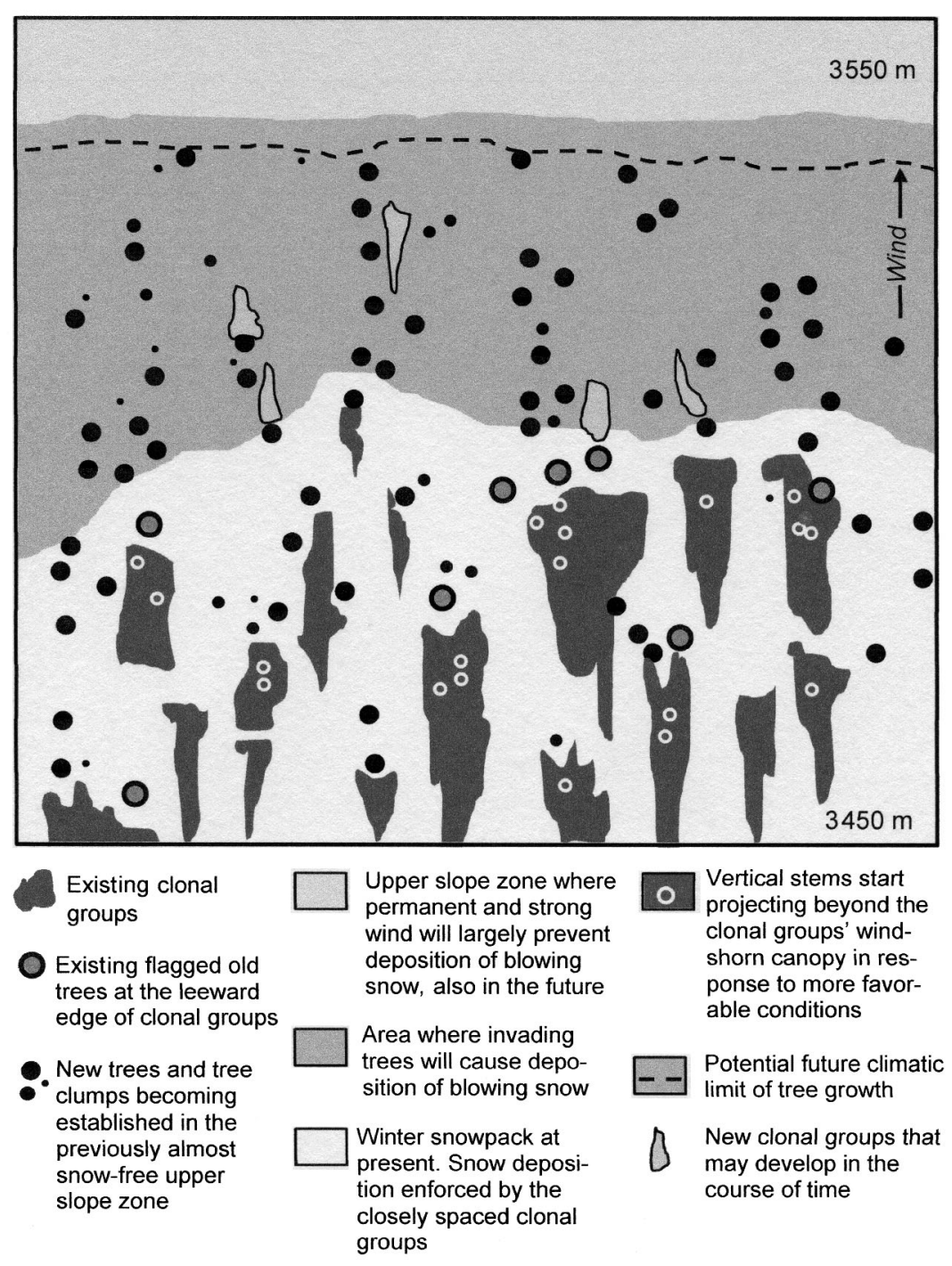

Fig. 8. Schematic representation of possible spatial dynamics in the tree-line ecotone with special regard to snow pattern. On wind-exposed slopes, where the winter snow cover would normally be very patchy or even absent, relatively large areas are buried under a deep and late-lying snowpack as existing tree groups and new trees reduce wind velocity and increase surface roughness

species that are intolerant of severe wind impact, deep frost and desiccation, such as Vaccinium myrtillus. On the other hand, dieback of snow-trapping multi-stemmed birch clusters exposes plants or parts of plants in the understory to severe winter injuries, in particular if terrain is wind-exposed. Thus, after mountain birch had declined due to mass-outbreak of the autumnal moth Epirrita autumnata in the mid1960s (Kallio \& Lehtonen 1973, 1975, Holtmeier 1974) common juniper Juniperus communis, previously well protected by the winter snowpack in the birch stands, was exposed to severe damage by frost, desiccation and ice particle abrasion (Holtmeier 2005).
In general, plants buried under snow are less tolerant of winter-desiccation than plants projecting above the winter snowpack (e.g. Havranek 1993, Neuner 2007).

\section{CLIMATE CHANGE AND FEEDBACK EFFECTS OF TREE GROUPS}

Climate warming may promote establishment of trees in the treeline ecotone possibly up to a new upper physiological limit of tree growth (Fig. 8) (see also Mathisen 2013, Hofgaard et al. 2013). However setbacks due to extreme events may occur. For example, strong frosts early in the growing season and in summer (e.g. Wardle 1968, Tranquillini 1979, Kauhanen 1987), lasting summer drought periods, extremely snow-rich winters or lack of snow could occur that can adversely affect seedling establishment and performance. Seedling recruitment may also fail, for example due to scarce availability of safe microsites (e.g. Resler et al. 2005, Ninot et al. 2008, Batllori et al. 2009).

When considering feedback effects of tree groups, changes in winter climatic conditions are of particular interest. Observations and modelbased predictions, however, show great regional variation due to climate regime and elevation (Brown \& Mote 2009, Räisänen \& Eklund 2012, Mountain Research Initiative EDW Working Group 2015). Thus, in Northern Europe, the number of days with fresh snow is projected to decrease most in the coastal regions and least in the mountain areas. Winter precipitation in northern Europe is projected to decrease by 20 to $30 \%$ (Lehtonen et al. 2013). The snowpack season decreased by $\sim 10 \mathrm{~d}$ between 2002 and 2011 . In the central Alps, precipitation is not expected to change a great deal at high elevations during the coming decades. The number of days with fresh snow, however, may be reduced by about $3 \mathrm{wk}$ (MeteoSchweiz 2013). An increase in snowfall is possible in the North American cordillera, while there is little evidence of increasing snow in northern 
Canada (Brown \& Mote 2009). On the other hand, in the high Colorado Rocky Mountains, the timing of snowmelt at high elevations has shifted toward earlier in the year (in March or April) (Clow 2010). Under these changing climatic conditions, the feedback mechanisms themselves will not change fundamentally; however, the effects on the treeline environment may be modified.

On wind-swept topography, infilling of gaps between existing clonal groups and increasing release of vertical stems from their wind-shorn compact surface (e.g. Caccianiga \& Payette 2006, Devi et al. 2008, Kullman 2015) will enhance deposition of blowing snow (cf. Fig. 4). This might be the most important effect of climate change in the ecotone. More wet snow, however, would reduce wind-mediated snow relocation.

More snow is expected to protect potential young growth from adverse climatic factors. It has been argued that at the alpine treeline of white spruce Picea glauca, winter conditions rather than summer temperatures are critical for seedling establishment (Renard et al. 2016). Moisture supply from melting snow might facilitate germination of seeds and support tree seedlings as well as ground vegetation. This may be of particular importance on dry southern exposures (see also Elliott \& Kipfmueller 2010, Elliott \& Cowell 2015). Clonal groups and tree clusters as well may also facilitate seed-based establishment of other species such as pine, spruce, fir and mountain birch (in northern Europe), at their lee side where these are protected from prevailing winds. On the other hand, late-lying snowpack will shorten the growing season, delay rise of soil temperature and increase the risk of potential seedlings being destroyed by settling of wet snow and/or by parasitic snow fungi (cf. Fig. 4). Moreover, increase of stem breakage and tension cracks due to heavy snow loads, snow creep and wind pressure is likely, while layering will not be affected. Some clonal groups, however, may die back, mainly due to recurrent damage by heavy snow loads. Seedling establishment, however, is not always linked to the presence of clonal and other compact tree groups. Microgeomorphic structures such as solifluctionterrace risers, large stones and boulders, shallow depressions, grass tussocks, cushion plants and dwarf shrubs may also facilitate seedlings (Holtmeier \& Broll 1992, 2010, 2012, Holtmeier 1996, Butler et al. 2009, Malanson et al. 2009, Elliott \& Kipfmueller 2010).

Geomorphic micro-structures, in particular wind scarps that have developed at the wind-exposed edge and lateral sides of migrating clonal groups may gradually become disguised by expanding grasses, shrubs and herbaceous vegetation (cf. Fig. 8). Moreover, the feedbacks from a single clonal group will become less obvious when new trees become established within the existing gaps between clonal groups. Clonal groups may also expand and increase in height, mainly due to emergence of vertical stems (e.g. Kullman 1979, 1986, 2007, Holtmeier 1985b, Lescop-Sinclair \& Payette 1995).

Due to the changing spatial structures and surface properties (roughness, albedo) the entire ecotone will change. However, heating of the lower atmosphere, suggested as a consequence of the northward migration of the polar treeline ecotone (e.g. Sturm et al. 2005), has been less than expected (Chapin et al. 2005). In rugged high-mountains, the lower alpine area with the potential to become covered with forest and tree stands is usually too small for such an effect to occur (Holtmeier 2009, Holtmeier \& Broll 2009, 2012, Mathisen 2013, Mathisen et al. 2014), compared to rolling subarctic/arctic landscapes where the polar treeline ecotone may shift northward hundreds of kilometers (Callaghan et al. 2002a, Callaghan et al. 2002b, Harding et al. 2002).

However, positive feedback effects of expanding mountain birch forest on warming as a result of reduced snow cover and lower albedo were found in south-central Norway (de Wit et al. 2014). In the Swiss Alps, the upward shift of the climatic snowline is expected to cause a significant heating as the exposed ground will absorb incoming solar radiation and warm up during a longer snow-free season (Pepin et al. 2015).

Infilling of the gaps between clonal groups and tree clusters will also bring about changes in biodiversity (see also Grace et al. 2002, Hofgaard et al. 2012). While subalpine species may profit from deeper snowpack, snow-intolerant species will only survive on wind-swept topography where snowpack is absent or episodic in winter. In better windprotected sites, diversity generally decreases in response to increasing tree cover (e.g. Malanson et al. 2007). In the long term, the new trees that can establish themselves beyond the present upper limit of clonal groups (cf. Fig. 8) might reproduce by layering and give rise to clonal groups that may persist for centuries or longer, even if climate deteriorates again. Thus, these groups would contribute to stabilization of the future treeline ecotone. New clonal groups of mountain birch and multi-stemmed mountain birch sprouting from the rootstock (basal shoots) could have a similar effect. 


\section{CONCLUSIONS}

Compact clonal groups and tree clusters influence their sites and those in close vicinity mainly by their effects on direct solar radiation and on ground-level wind-flow. The black-body effect occasionally facilitates establishment of seedlings at the sun-exposed side of trees and tree groups.

Small-scale wind-mediated relocation of snow is a key factor in the treeline ecotones considered. Tree clusters can accumulate large quantities of drifting snow. Compact clonal groups produce a long and deep snowdrift behind their leeward edge. Increased snow accumulation may have both positive and negative effects on site conditions, seedling establishment and survival of young trees. Deep snow prevents soils from freezing, provided that the soil was not frozen already before the snow accumulated. Increased soil moisture mitigates drought stress at the beginning of the growing season. On the other hand, infiltrating meltwater and evaporation delay warming of the soil. Late-laying snowdrifts shorten the growing season and may impair tree seedlings that establish themselves in the snowdrift site. In addition they may be affected by snow fungi and mechanical damage caused by settling snow.

The relative effects of clonal groups and compact tree clusters vary depending on local conditions. Thus, in dry climates and on southern aspects, increased moisture supply as a result of snow deposition caused by the tree groups appears to be more important than on northern exposures, which are usually rich in snow anyway (see also Elliott \& Kipfmueller 2010).

Locally, trapped eolian dust (alpine loess) and wind-blown organic particles both play an important role. Eolian dust influences soil nutrient content, soil acidity, water-storing capacity, heat conductivity and decomposition. Downwind 'migrating' clonal groups may lastingly influence soils and leave micro-geomorphic structures in the ecotone. No comparable effects of tree clusters can be found.

Climate change will bring about far-reaching changes in treeline spatial structures, dynamics, and in biodiversity. On terrain currently covered with clonal groups, the infilling of existing gaps with trees and tree clusters might be the most important effect (e.g. Harding et al. 2002). Development of new clonal groups at higher elevation and beyond the northern treeline will increase the persistence of the future treeline as they reduce wind velocity and increase deposition of drifting snow and may also act as a new source of viable seeds. On the other hand, wildfires, which are likely to increase under warmer and drier conditions, may adversely affect clonal groups, tree clusters and young trees occupying gaps in the present treeline ecotone, even at sites where wildfires are absent under current conditions.

Warming of the lower atmosphere might result from a poleward shift of the northern coniferous treeline. However such an effect cannot be expected in rugged high-mountains, because on steep slopes the lower alpine area with potential to become covered with forest and tree stands is usually of too small a scale to have this effect. The retreating climatic snowline is more likely to contribute to a warming of the lower atmosphere. Conditions may be different on undulating smooth topography as, for example, in northern Finland and in many areas of the Rocky Mountains, where the treeline ecotone often extends over old uplifted land surfaces. However, since a multitude of regionally and locally varying factors are involved, prognoses of the possible influence of increasing tree populations on warming of the lower atmosphere are uncertain.

Acknowledgements. We are grateful to the COST action SENSFOR (Enhancing the resilience capacity of SENSitive mountain FORest ecosystems under environmental change) for support. Our thanks go to Professor R. M. M. Crawford (St. Andrews University) for revising the English text.

\section{LITERATURE CITED}

Alftine KJ, Malanson GP (2004) Directional positive feedback and pattern at an alpine tree line. J Veg Sci 15:3-12 Anschlag K, Broll G, Holtmeier FK (2008) Mountain birch seedlings in the treeline ecotone, Subarctic Finland. Variation in above- and belowground growth in relation to microtopography. Arct Antarct Alp Res 40:609-616

Aulitzky H (1961) Die Bodentemperaturen in der Kampfzone oberhalb der Waldgrenze und im subalpinen Zirben-Lärchenwald. Mitteilungen der Forstlichen Bundes-Versuchsanstalt Mariabrunn 59:155-208

Barbeito I, Brücker RL, Rixen C, Bebi P (2013) Snow fungiinduced mortality of Pinus cembra at the alpine treeline: evidence from plantations. Arct Antarct Alp Res 45: 455-470

* Batllori E, Camarero JJ, Ninot JM, Gutiérrez E (2009) Seedling recruitment, survival and facilitation in alpine Pinus uncinata tree line ecotones. Implications and potential responses to climate warming. Glob Ecol Biogeogr 18:460-472

* Bekker MF (2005) Positive feedbacks between tree establishment and patterns of subalpine forest advancement, Glacier National Park, Montana, USA. Arct Antarct Alp Res 37:97-107

Benedict JB (1984) Rates of tree-island migration, Colorado Rocky Mountains. Ecology 65:820-823

Blanken PD (2009) Designing a living snow fence for snow drift control. Arct Antarct Alp Res 41:418-425 
Brink VC (1959) A directional change in the subalpine forest-heath ecotone in Garibaldi-Park, British Columbia. Ecology 40:10-16

* Brodersen CR, Germino MJ, Smith WK (2006) Photosynthesis during an episodic drought in Abies lasiocarpa and Picea engelmannii across an alpine treeline. Arct Antarct Alp Res 38:34-41

Broll G, Holtmeier FK (1994) Die Entwicklung von Kleinreliefstrukturen im Waldgrenzökoton der Front Range (Colorado, USA) unter dem Einfluß leewärts wandernder Ablegergruppen (Picea engelmannii und Abies lasiocarpa). Erdkunde 48:48-59

Brooks PD, Williams MW, Walker DA, Schmidt SK (1995) The Niwot Ridge snow fence experiment: biogeochemical response to changes in seasonal snowpack. Biogeochemistry of seasonally snow-covered catchments. In: Tonessen KA, Williams MW, Tranter M (eds) Biogeochemistry of seasonally snow-covered catchments. Proc Symp, Boulder 1995. Publication 228, International Association of Hydrological Sciences (IAHS), Wallingford, p 293-302

Brown RD, Mote PW (2009) The response of northern hemisphere snow cover to a changing climate. J Clim 22: 2124-2145

Butin H (2011) Krankheiten der Wald- und Parkbäume. Diagnose - Biologie - Bekämpfung, 4th edn. Verlag Eugen Ulmer, Stuttgart

Butler DR, Malanson GP, Resler LM, Walsh SJ, Wilkerson FD, Schmid GL, Sayer CF (2009) Geomorphic patterns and processes at alpine treeline. In: Butler DR, Malanson GP, Walsh SF, Fagre DB (eds) The changing alpine timberline: the example of Glacier National Park, MT, USA. Elsevier, Amsterdam, p 62-84

Bylund $H$ (1999) Climate and the population dynamics of two insect outbreak species in the north. In: Hofgaard A, Ball JP, Danell K, Callaghan T (eds) Animal responses to global change in the north. Ecol Bull 47: 54-62

Caccianiga M, Payette S (2006) Recent advance of white spruce (Picea glauca) in the coastal tundra of the eastern shore of Hudson Bay (Québec, Canada). J Biogeogr 33: 2120-2135

Callaghan TV, Crawford RMM, Eronen M, Hofgaard A and others (2002a) The dynamics of the tundra-taiga boundary: an overview and suggested coordination and integrated approach to research. Ambio 12:3-5

Callaghan TV, Werkman BR, Crawford RMM (2002b) The tundra-taiga interface and its dynamics: concepts and applications. Ambio 12:6-14

Callaway RM, Brooker RW, Choler P, Kikvidzer Z and others (2002) Positive interactions among alpine plants increase with stress. Nature 417:844-848

Chapin FS, Sturm M, Serreze MC, McFadden JP and others (2005) Role of land-surface changes in arctic summer warming. Science 310:657-660

Clow DW (2010) Changes in timing of snowmelt and streamflow in Colorado: a response to recent warming. J Clim 23:2293-2306

* Cunningham C, Zimmermann NE, Stoeckli V, Bugmann H (2006) Growth response of Norway spruce saplings in two forest gaps in the Swiss Alps to artificial browsing, infection with black snow mold and competition by ground vegetation. Can J Forest Res 36:2782-2793

Daly C (1984) Snow distribution pattern in the alpine krummholz zone. Prog Phys Geogr 8:157-175

de Wit HA, Bryn A, Hofgaard A, Karstensen J, Kvalevåg MM, Peters GP (2014) Climate warming feedback from mountain birch forests expansion: reduced albedo domi- nates carbon uptake. Glob Change Biol 20:2344-2355

* Devi N, Hagedorn F, Moiseev P, Bugmann H, Shiyatov S, Mazepa V, Rigling A (2008) Expanding forest and changing growth forms of Siberian larch at the polar Urals treeline during the 20th century. Glob Change Biol 14: 1581-1591

Dyunin AK (1967) Fundamentals of the mechanics of snow storms. In: Ohmura (ed) Physics of snow and ice. Proc Conf Physics of Snow and Ice. II. Cryobiology, Sapporo, 14-19 Aug 1966. Institute of Low Temperature Science, Hokkaido University, p 1965-1173

* Elliott GP (2012) The role of thresholds and fine-scale processes in driving upper treeline dynamics in the Bighorn Mountains, Wyoming. Phys Geogr 33:129-145

Elliott GP \& Cowell CM (2015) Slope aspect mediates finescale tree establishment patterns at upper treeline during wet and dry periods of the 20th Century. Arct Antarct Alp Res 478:679-690

* Elliott GP, Kipfmueller KF (2010) Multi-scale influences of slope aspect and spatial pattern on ecotonal dynamics at upper treeline in the Southern Rocky Mountains, USA. Arct Antarct Alp Res 42:45-56

Franklin JF, Dyrness CT (1973) Natural vegetation of Oregon and Washington. General Technical Report PNW-8, USDA Forest Service, Portland, OR

Germino MJ, Smith WK (1999) Sky exposure, crown architecture, and low-temperature photoinhibition in conifer seedlings at alpine treeline. Plant Cell Environ 22: 407-415

* Germino MJ, Smith WK, Resor AC (2002) Conifer seedling distribution and survival in an alpine treeline ectone. Plant Ecol 162:157-168

Grace J, Berninger F, Nagy L (2002) Impacts of climate change on tree line. Ann Bot 90:537-544

Habeck JR (1969) A gradient analysis of a timberline zone at Logan Pass, Glacier Park, Montana. Northwest Sci 43: 65-73

*Hadley JL, Smith WK (1986) Wind effects on needles of timberline conifers: seasonal influences on mortality. Ecology 67:12-19

*Harding R, Khury P, Christensen TR, Sykes MT, Dankers R, Van der Linden S (2002) Climate feedbacks at the tundra-taiga interface. Ambio 12:47-55

*Harsch MA, Hulme PE, McGlone MS, Duncan RP (2009) Are treelines advancing? A global meta-analysis of treeline response to climate warming. Ecol Lett 12:1040-1049

Havranek WM (1993) The significance of frost and frostdrought for the alpine timberline. In: Anfodillo $\mathrm{T}$, Urbinati C (eds) Ecologia delle Foreste di Alta Quota. Proc XXX Corso di Cultura in Ecologia. Università di Padova, p 115-117

Havranek W, Tranquillini W (1995) Physiological processes during winter dormancy and their ecological significance. In Smith WK, Hinckley TM (eds) Ecophysiology of forests. Academic Press, New York, NY, p 95-124

*Hiemstra CA, Liston GE, Reiners WA (2002) Snow redistribution by wind and interactions with vegetation at upper treeline in the Medicine Bow Mountains, Wyoming, USA. Arct Antarct Alp Res 34:262-273

* Hiemstra CA, Liston GE, Reiners WA (2006) Observing, modelling and validating snow redistribution in a Wyoming upper treeline landscape. Ecol Modell 197:35-51

* Hinkel KM, Hurd JK (2006) Permafrost destabilization and thermokarst following snow fence installation, Barrow, Alaska, USA. Arctic Antarct Alp Res 38:530-539

Hoch G, Körner C (2003) The carbon charging of pines at the climatic treeline: a global comparison. Oecologia 135: 
$10-21$

Hofgaard A, Harper A, Golubeva E (2012) The role of circumarctic forest-tundra ecotone for Arctic biodiversity. Biodiversity 13:174-181

Hofgaard A, Tömmervik H, Rees G, Hanssen F (2013) Latitudinal forests advance in northernmost Norway since the early 20th century. J Biogeogr 40:938-949

Holtmeier FK (1978) Die bodennnahen Winde in den Hochlagen der Indian Peaks Section, Colorado Front Range. Münstersche Geographische Arbeiten 3:3-47

Holtmeier FK (1974) Geoökologische Beobachtungen und Studien an der subarktischen und alpinen Waldgrenze in vergleichender Sicht (nördliches Fennoskandien/Zentralalpen). Erdwissenschaftliche Forschung 8, Steiner Verlag, Wiesbaden

Holtmeier FK (1980) Influence of wind on tree-physiognomy at the upper timberline in the Colorado Front Range. In Benecke U, Davis MR (eds) Mountain environments and subalpine tree growth. Forest Research Insitute Technical Paper 70, New Zealand Forest Service, Wellington, p 247-251

Holtmeier FK (1985a) Die klimatische Waldgrenze-Linie oder Übergangssaum (Ökoton)? Ein Diskussionsbeitrag unter besonderer Berücksichtigung der Waldgrenze in den mittleren und hohen Breiten der Nordhalbkugel. Erdkunde 39:271-285

Holtmeier FK (1985b) Climatic stress influencing the physiognomy of trees at the polar and mountain timberline. Eidgenössische Anstalt für das forstliche Versuchswesen, Berichte 270:31-40

Holtmeier FK (1987) Beobachtungen und Untersuchungen über den Ausaperungsverlauf und einige Folgewirkungen in 'ribbon-forests' und an der oberen Waldgrenze in der Front Range, Colorado. Phytocoenologia 15:373-396

Holtmeier F-K (1996) Die Wirkungen des Windes in der subalpinen und alpinen Stufe der Front Range, Colorado, USA. Arbeiten aus dem Institut für Landschaftsökologie 1:15-45

Holtmeier FK (1999) Ablegerbildung im Hochlagenwald und an der oberen Waldgrenze in der Front Range, Colorado. Mitt Deutsch Dendrol Ges 84:39-61

Holtmeier F-K, Broll G, Müterthies A, Anschlag K (2003) Regeneration of trees in the treeline ecotone, northern Finnish Lapland. Fennia 181:103-128

Holtmeier FK (2005) Relocation of snow and its effects in the treeline ecotone - with special regard to the Rocky Mountains, the Alps and Northern Europe. Erde 136:343-373

Holtmeier FK (2009) Mountain timberlines: ecology, patchiness, and dynamics, 2nd edn. Advances in Global Change Research 36, Springer, Dordrecht

Holtmeier FK, Broll G (1992) The influence of tree islands on microtopography and pedoecological conditions in the forest-alpine tundra on Niwot Ridge, Colorado Front Range, USA. Arct Alp Res 24:216-228

Holtmeier FK, Broll G (2009) Altitudinal and polar treelines in the northern hemisphere - causes and response to climate change. Polarforschung 79:139-153

Holtmeier FK, Broll G (2010) Wind as an ecological agent at treelines in North America, the Alps, and the European Subarctic. Phys Geogr 31:203-233

Holtmeier F-K, Broll G (2011) Response of Scots Pine (Pinus sylvestris) to warming climate at its altitudinal limit in northernmost subarctic Finland. Arctic 64: 269-280

Holtmeier FK, Broll G (2012) Landform influences on treeline patchiness and dynamics in a changing climate. Phys Geogr 33:403-437

Holtmeier FK, Broll G, Anschlag K (2004) Winderosion und ihre Folgen im Waldgrenzbereich und in der alpinen Stufe einiger nordfinnischer Fjelle. Geo-öko 25:203-224

*Humphries HC, Bourgeon PS, Mujica-Crapanzano LR (2008) The spatial patterns and environmental relationships in the forest-alpine tundra ecotone at Niwot Ridge, Colorado, USA. Ecol Res 23:589-605

Johnson DM, Germino MJ, Smith WK (2004) Abiotic factors limiting photosynthesis in Abies lasiocarpa and Picea engelmannii seedlings below and above the alpine timberline. Tree Physiol 24:377-386

Kallio P, Lehtonen J (1973) Birch forest damage by Oporinia autumnata (Bkh.) in 1965-1966 in Utsjoki, N Finland. Rep Kevo Subarct Res Stn 10:55-69

Kallio P, Lehtonen J (1975) On the ecocatastrophe of birch forest caused by Oporinia autumnata (Bkh.) and the problem of reforestation. In: Wielgolaski FE (ed) Fennoscandian tundra ecosystems. 2. Animals and system analysis. Ecological Studies 17, Springer, Berlin, p 174-180

Karlsson PS, Nordell O (1996) Effects of soil temperature on the nitrogen economy and growth of mountain birch seedlings near its presumed low temperature distribution limit. Ecoscience 3:183-189

Kauhanen H (1987) On growth problems of mountain birch near its distributional limits. In: Alexanderson $\mathrm{H}$, Holmgren B (eds) Climatological extremes in mountains. UNGI (Uppsala universitet, Naturgeogrfiska institutionen) 65:183-190

Kharuk VI, Ranson KJ, Im ST, Vdovin AS (2010) Spatial distribution and temporal dynamics of high elevation forest stands in southern Siberia. Glob Ecol Biogeogr 19:822-830

Kobayashi D (1972) Studies of transport in low level drifting snow. Contributions from the Institute of Low Temperature Science, Serie A 24:1-58

Kramer PJ (1982) Water relations of plants. Academic press, New York, NY

Kullman L (1979) Change and stability in the altitude of the birch tree-limit in the southern Swedish Scandes 1915-1975. Acta Phytogeographica Suecica 65, Uppsala

Kullman L (1986) Recent tree-limit history of Picea abies in the southern Swedish Scandes. Can J For Res 16: 761-771

Kullman L (2007) Modern climate change and shifting ecological states of the subalpine/alpine landscape in the Swedish Scandes. Geo-öko 28:187-221

Kullman L (2012) The alpine treeline ecotone in the southwestern Swedish Scandes: dynamics on different scales. In Myster RW (ed) Ecotones between forest and grassland. Springer, New York, NY, p 271-298

Kullman L (2015) Norway spruce (Picea abies (L.) Karst.). Treeline performance since the mid-1970s in the Swedish Scandes - evidence of stability and minor change from repat surveys and photography. Geoöko 36: 25-53

Larcher W (1980) Klimastress im Gebirge-Adaptionstraining und Selektionsfilter für Pflanzen. Rheinisch-Westfälische Akademie der Wissenschaften. Rheinisch-Westfälische Akad Wiss Vorträge 291:49-80

Lehtonen I, Venäläinen A, Ikonen J, Puttonen N, Gregory H (2013) Some features of winter climate in northern Fennoscandia. Finnish Meteorological Institute Reports 2013 (3), Unigrafia, Helsinki

Lescop-Sinclair PS, Payette S (1995) Recent advance of the arctic treeline along the eastern coast of Hudson Bay. J Ecol 83:929-936

Kiston GE, McFadden JP, Sturm N, Pielke RA Sr (2002) Modelled changes in arctic tundra snow, energy and moisture fluxes due to increased shrubs. Glob Change Biol 8: $17-32$ 
Litaor MI (1987) The influence of eolian dust on the genesis of alpine soils in the Front Range, Colorado. Soil Sci Soc Am J 51:142-147

Maher EL, Germino MJ (2006) Microsite differentiation among conifer species during seedling establishment at alpine treeline. Bioscience 13:334-341

Malanson GP, Butler DR, Fagre DB, Walsh SJ and others (2007) Alpine treeline of western North America: linking organism-to-landscape dynamics. Phys Geogr 28: 378-396

Malanson GP, Brown DG, Butler DR, Cairns DM, Fagre DB, Walsh SJ (2009) Ecotone dynamics: invisibility of alpine tundra. In Butler DR, Malanson GP, Walsh SF, Fagre DB (eds) The changing alpine timberline: the example of Glacier National Park, MT, USA. Elsevier, Amsterdam, p 35-61

Marr JW (1966) The development and movement of tree islands near the upper limit of tree growth in the southern Rocky Mountains. Ecology 58:1159-1164

Mathisen EI (2013) Structure, dynamic sand regeneration capacity at the subarctic forest-tundra ecotone of northern Norway and Kola Peninsula, NW Russia. Doctoral thesis, Norwegian University of Science and Technology, Trondheim

MeteoSchweiz (2013) Klimaszenarien Schweiz: eine regionale Übersicht. Fachbericht 243, MeteoSchweiz, Zürich

Mountain Research Initiative EDW Working Group (2015) Elevation-dependent warming in mountain regions of the world. Nat Clim Change 5:424-430

Neuner G (2007) Frost resistance at the upper timberline. In: Wieser G, Tausz M (eds) Trees at their upper limit: treelife limitation at the upper timberline. Plant Ecophysiology 5, Springer, Dordrecht, p 171-180

Neuvonen S, Wielgolaski FE (2005) Herbivory in northern birch forests. In: Wielgolaski FE (ed) Plant ecology, herbivory, and human impact in Nordic mountain birch forests. Springer, Berlin p 183-189

Nierhaus-Wunderwald D (1996) Pilzkrankheiten in Hochlagen, Biologie und Befallsmerkmale. Wald und Holz 10: $18-24$

Ninot JM, Batllori E, Carillo E, Carreras J, Ferré A, Gutiérrez E (2008) Timberline structure and limited tree recruitment in the Catalan Pyrenees. Plant Ecol Divers 1:47-51

Öberg L, Kullman L (2011) Ancient subalpine clonal spruces (Picea abies): sources of postglacial vegetation history in the Swedish Scandes. Arctic 64:183-196

Oke TR (1987) Boundary layer climates, 2nd edn. Routledge, London

Pepin N, Bradley RS, Diaz HF, Baraer M and others (2015) Elevation-dependent warming in mountain regions of the world. Nat Clim Change 5:424-430

Räisänen J, Eklund J (2012) 21st century changes in snow climate in Northern Europe: a high resolution view from ENSEMBLES regional climate models. Clim Dyn 38:2575

Renard SM, McIntire EJB, Fajrado A (2016) Winter conditions - not summer temperature - influence establishment of seedlings at white spruce alpine treeline in Eastern Quebec. J Veg Sci 27:29-39

Resler LM (2006) Geomorphic controls of spatial pattern and process at alpine treeline. Prof Geogr 58:124-138

Resler LM, Butler DR, Malanson GP (2005) Topographic shelter and conifer establishment and mortality in an alpine environment, Glacier National Park, Montana. Phys Geogr 26:112-125
Roll-Hansen F (1989) Phacidium infestans: a literature review. Eur J Forest Pathol 19:237-250

Schumacher S, Bugmann H (2006) The relative importance of climatic effects, wildfires and the management for future forest landscape dynamics in the Swiss Alps. Glob Change Biol 12:1435-1450

Senn J (1999) Tree mortality caused by Gremeniella abietina in subalpine afforestations in the central Alps and its relationship with duration of snow cover. Eur J Forest Pathol 29:65-75

Shi P, Körner C, Hoch G (2006) End of season carbon supply status of woody species near the treeline in western China. Basic Appl Ecol 7:370-377

Skre O (1993) Growth of mountain birch (Betula pubescens Ehrh.) in response to changing temperature. In Alden J, Mastrantonio JL, Ødum S (eds) Forest development in cold climates. Plenum Press, New York, NY, p 65-78

* Smith WK, Germino MJ, Hancock TE, Johnson DM (2003) Another perspective on altitudinal limits of alpine timberlines. Tree Physiol 23:1101-1112

Stöcklin J, Körner C (1999) Recruitment and mortality of Pinus sylvestris near the Nordic treeline: the role of climatic change and herbivory. Ecol Bull 47:168-177

Streule A, Häsler R (2006) Windschutz für junge Bäume in subalpinen Aufforstungen an stark windexponierten Wuchsorten 'Pru dal Vent' (Alp Grüm, GR). Eidgenössische Anstalt für Wald, Schnee und Landschaft WSL, Birmensdorf

* Sturm K, Douglas T, Racine R, Liston G (2005) Changing snow and shrub conditions affect albedo with global implications. J Geophys Res 110:1-3

K Sveinbjörnsson B, Nordell O, Hauhanen H (1992) Nutrient relations of mountain birch growth at and below the elevational tree line in Swedish Lapland. Funct Ecol 6: $213-220$

* Tape K, Sturm M, Racine C (2006) The evidence for shrub expansion in Northern Alaska and the Pan-Arctic. Glob Change Biol 12:686-702

Thorn CE, Darmody RG (1985) Grain-size distribution of the insoluble compontents of contemporary eolian deposits in the alpine zone, Front Range, Colorado. Arct Alp Res $17: 433-442$

* Tranquillini W (1957) Standortsklima, Wasserbilanz und $\mathrm{CO}_{2}$-Gaswechsel junger Zirben (Pinus cembra L.) an der alpinen Waldgrenze. Planta 49:612-661

Tranquillini W (1979) Physiological ecology of the alpine timberline: tree existence at high altitudes with special reference to the European Alps. Ecological Studies 31, Springer, Berlin

Turner H, Streule A (1983) Wurzelwachstum und Sprossentwicklung junger Koniferen im Klimastress der alpinen Waldgrenze, mit Berücksichtigung von Mikroklima, Photosynthese und Stoffproduktion. In: Böhm W et al. (eds) Wurzelökologie und ihre Anwendung. Internationales Symposium Gumpenstein 1982. Bundesanstalt Gumpenstein, Irdning, p 617-635

*Wardle P (1968) Engelmann spruce (Picea Engelmannii ENGEL) at its upper limit in the Front Range, Colorado. Ecology 49:483-495

Weiss DJ, Malanson GP, Walsh SJ (2015) Multiscale relationships between alpine treeline elevation and hypothesized environmental controls in the western United States. Ann Assoc Am Geogr 105:437-453

Keng Y, Malanson GP (2006) Endogenous fractal dynamics at alpine treeline ecotones. Geogr Anal 38:271-287

Submitted: April 7, 2016; Accepted: September 15, 2016

Proofs received from author(s): December 3, 2016 